\title{
Ecologists seek to turn tide on Colorado River
}

Rex Dalton, El Golfo de Santa Clara

Scientists and environmental groups are battling on several fronts to try to revive the Colorado River delta, a once-vibrant ecosystem in the Mexican desert.

In US courtrooms, in diplomatic meetings and even on the waterways of the delta itself, advocates are trying to secure the primary component that can enhance the region: the flow of fresh water. With almost all of the Colorado's flow extracted for irrigation and water supply in the United States, the river is reduced to a tiny stream by the time it arrives at the Gulf of California in Mexico.

On 4 June, the US District Court in Washington rejected a lawsuit filed by seven environmental groups to force US authorities to let more water flow into Mexico from the Colorado's vast watershed, under the US Endangered Species Act. They claimed that the reduced flow is endangering several species of fish and shellfish.

But ecologists are optimistic that international action can restore the delta's ecosystem. On the same day as the court case, the International Boundary and Water Commission in El Paso, Texas - a joint agency set up by Mexico and the United States - held the first meeting of a binational forum founded to recommend plans to save the delta.

The region will also be on the agenda when senior environmental officials from the United States, Mexico and Canada meet in Washington next week under the auspices of the Commission for Environmental Cooperation - an offshoot of the North American Free Trade Agreement (NAFTA) — to review a list of priority conservation areas.

Advocates want the United States to release about 37 million cubic metres of water per year into the river, with an extra pulse every four or five years if normal floods don't occur naturally.

Meanwhile, researchers from both Mexico and the United States are at work in the area, and are finding that it badly needs more fresh water. Their work is often perilous, because fisherman suspect that the research might damage their livelihoods and drugs smugglers are active in the area.

In March, geologist Karl Flessa of the University of Arizona at Tucson found that the delta's salinity level is nearly twice as high as normal, which is believed to be endangering a clam species, Mulinia coloradoensis.

Lorenzo Rojas Bracho, a coastal oceanographer from Ensenada, Mexico, is conducting acoustic surveys to count vaquita (Phocoena sinus), a type of porpoise that is under threat from heavy and sometimes illegal fishing in the gulf. "I don't see how we can save the delta without a real commitment from both nations," says Rojas Bracho.

The drive to save the delta hasn't enjoyed

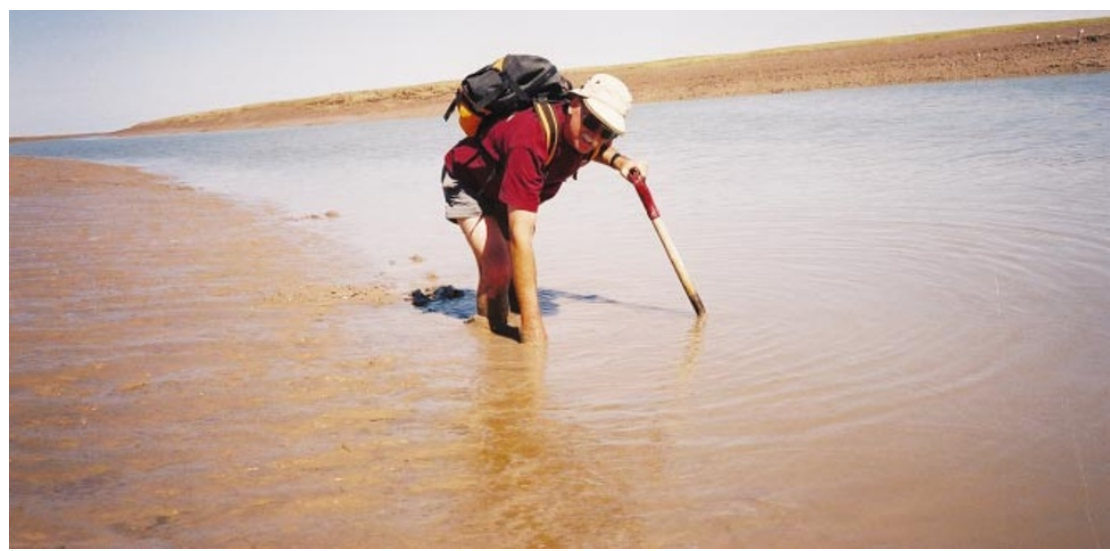

Drying up: Karl Flessa thinks that the decreased flow of the Colorado River is endangering shellfish.

the profile of the decades-long struggle to conserve the Florida Everglades, for example. But it is becoming urgent as economic and ecological stresses threaten to eliminate the last vestiges of a lush riverbank system that existed 75 years ago, before US dams harnessed most of the river's natural flow.

"This is a huge issue," says Lance Morgan, chief scientist at the Marine Conservation Biology Institute in Redmond, Washington.
"We will witness major extinctions in our lifetime if a strong binational agreement isn't reached." Species at risk include clams, shrimp and fish.

Some ecologists are encouraged by a US Bureau of Reclamation plan, whereby the federal government could purchase water from US farmers for release down the Colorado River into Mexico. However, the plan is expected to meet resistance in Congress.

\section{Hive beetle causes a buzz in Europe}

\section{Philipp Graf, Munich}

A new predator could be set to sweep through central Europe's beehives - and angry bee-keepers are asking the European Union to keep it at bay by banning all honeybee imports.

The parasite in question - a small hive beetle - has destroyed thousands of honeybee colonies in the United States over the past five years. Now bee-keepers fear it could find its way to Europe, compounding problems caused by the Varroa destructor mite, which wiped out one-third of Europe's bee colonies last winter.

Larvae of the beetle, Aethina tumida, which is thought to originate in South Africa, tunnel through honeycombs and kill bee larvae. Infested colonies that do not die often leave their hives. The beetle is hard to eradicate, as it is very mobile and can live in wild bee or bumble-bee colonies, which potentially serve as a natural reservoir.

Since its first identification in Florida in 1998, the beetle has spread rapidly. It has also appeared in Egypt and Australia.

European bee-keepers have been importing queen bees and colonies from the United States and Australia to resupply their colonies after the Varroa attack. But this "poses a high risk for bringing in the beetles", says Jeff Pettis, an entomologist at the Beltsville Agricultural Research Center in Maryland.

German bee-keepers campaigning for an import ban claim that four times as many bee colonies as normal could be imported into Germany this year because of the mite pest losses. And France is drafting legislation for a complete ban on bee imports from affected countries.

Britain already restricts bee imports to queens brought from New Zealand and Hawaii. Now campaigners have won the backing of the German government for a Europe-wide ban on bee imports. A European Commission working group will discuss the proposal in Brussels on 24 June.

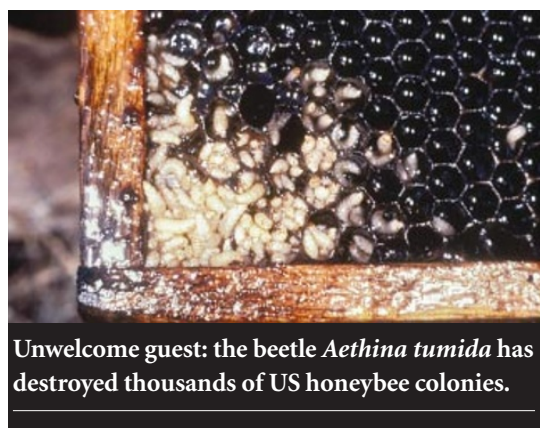

